\title{
EFFECT OF TEMPARUTRES ON THE DRYING BEHAVIORS AND QUALITY OF CITRUS PEELS
}

\author{
Shoughy, M. I. * and M. A. Abd El-Galeel**
}

\begin{abstract}
The changes in citrus peels $(C P)$ moisture content, drying rate, moisture ratio, drying time and energy consumption at various drying air temperatures was studied. The effect of drying temperatures and residual moisture contents on the quality of CP after drying was also evaluated. The test samples were dried in a laboratory scale hot air dryer at air temperature in the range of $40-70^{\circ} \mathrm{C}$ and a constant air velocity of $1 \mathrm{~m} / \mathrm{s}$ to desired moisture for save storage and final moisture level of drying conditions. Cakes prepared from blendes containing different proportion (0, 10, 15 and 20\%) of dried orange and mandarin peels were also evaluated for chemical composition and sensory attributes. The results indicated that, the drying temperature was very effective in removing moisture from citrus peels. The drying time was decreased by $50 \%$ and specific energy consumption decreased by about $28.5 \%$ with increasing drying temperature from 40 to $70^{\circ} \mathrm{C}$ for drying citrus peels. The simple exponential equation satisfactorily described the drying behavior of $C P$ as indicated by the higher coefficient of determination. The optimal drying temperature was $60^{\circ} \mathrm{C}$ to reach $10 \pm 0.2 \%$, w.b. moisture level, which reduced drying time and saved energy consumption and product quality. Meanwhile, overdrying to reach final moisture levels of citrus peels $(5.4 \pm 0.2 \%)$ with higher drying air temperature sharply increased the losses of vitamin $C$, carotenoids and essential oils. Incorporation $15 \%$ of dried orange and mandarin peels in cakes formula increased dietary fiber by 33.5 and $29.6 \%$, ether extract by 2.9 and $4.6 \%$ and ash by 30.6 and $29.0 \%$, respectively, while protein and total carbohydrates contents were slightly decreased. Highly acceptable cakes could be obtained by incorporating $15 \%$ of orange and mandarin peels dried to $10 \%, w . b .$, moisture content in the cakes formulation and it can be used as value-added food ingredients.
\end{abstract}

\footnotetext{
* Agric. Eng. Res. Inst. (AEnRI), Dokki, Giza, Egypt.

** Food Tech. Department, Fac. of Agric., Kafrelsheikh Univ.
} 


\section{INTRODUCTION}

$\mathrm{M}$ ost food processing residues in developing nations are disposed without being recycled and their utilization is sometimes limited as a result of their poor understanding of their nutritional and economic values. A disposal of these materials usually represents a problem that is further aggravated by legal restrictions. Usually, these by-products are used in animal feeding. Byproducts derived from food processing are attractive source for their valuable bioactive components and color pigments (Kong et al., 2010) and their high amount of dietary fiber could permit the use of them in developing new natural ingredients for the food industry. The peel which represents almost $50 \%$ of the fruit mass includes valuable compounds and an important source of bioactive compounds including antioxidants such as terpenoid, ascorbic acid (vitamin C), flavonoids, phenolic compounds that are important to human nutrition (Jayaprakasha and Patil, 2007). Dietary fiber of citrus peel is found in albedo which is a white, spongy and cellulosic tissue which is the principle components of the citrus peel and could be considered as a potential source of fiber. Epidemiological studies on dietary citrus flavonoids improved a reduction in risk of coronary heart disease (Di Majo et al., 2005) and is attracting more and more attention not only due to their antioxidant properties, anti-cancer, anti-viral, effects on capillary fragility, and an observed inhibition of human platelet aggregation but as anticarcinogenic and anti-inflammatory agents because of their lipid antiperoxidation effects (Marin et al., 2007). Carotenoids have received a tremendous amount of attention as potential anti-cancer and anti-ageing compounds. CP contains a high amount of carotenoids (Mortensen, 2006), thus, new aspects concerning the use of these wastes because these are high-value products and their recovery may be economically attractive (Djilas and Gordara, 2009). Due to the high moisture content of such residuals after processing, there is a need to rapidly drying for reduce the moisture content down to safe level before further process. Air drying is the most frequently used dehydration operation in the food industry, where the temperature of this operation is limited by the heat sensitivity of the material and expected quality of the final product 
(Lewicki, 2006)and (Inchuen et al., 2010). Therefore, there is a need to optimize the conditions to produce high-quality dried products. The specific objectives of this research were to study the effects of drying air temperatures on the drying behavior of $\mathrm{CP}$ and specific energy consumption for drying. The effects of drying air temperatures and residual moisture content on the quality of $\mathrm{CP}$ after drying and incorporation in cakes formula were also evaluated.

\section{MATERIALS AND METHODS}

\section{Sample preparation:}

Fresh citrus peels of Egyptian mandarin and sour orange were collected during 2012 season from household residuals and stored in refrigerator at $5 \pm 11^{\circ} \mathrm{C}$ until used. The initial moisture content was determined using hot air oven method at $60^{\circ} \mathrm{C}$ for $72 \mathrm{~h}$ (Wiriyaumpaiwong and Wiset, 2008). The moisture content of the sample on a wet weight basis (\%w.b.) was then calculated. The initial moisture content of mandarin peels was $79.6 \%$, w.b., and for orange peels of $76.4 \%$, w.b. To obtain the save storage moisture content of about $10 \%$ (w.b.), $773.3 \mathrm{~kg}$ water per $1000 \mathrm{~kg}$ fresh mass of mandarin peels and $737.8 \mathrm{~kg}$ water per $1000 \mathrm{~kg}$ fresh mass of orange peels had to be evaporated.

\section{Drying conditions:}

The collected peels were washed and minced to pieces and dried at the temperatures of $40,50,60$ and $70^{\circ} \mathrm{C}$. To eliminate the other factors affecting drying behaviors, the samples were dried in a single layer in a standard precision oven model $(\boldsymbol{R K J})$ as shown in Fig. 1. Heat was generated by the heaters integrated into the side walls of the oven and the hot air flowed by the fan through the samples. Because of velocity of drying air has no significant impact on drying behavior of thin layers, Doymaz (2006), a constant air velocity of $1 \mathrm{~m} / \mathrm{s}$ is used. The oven drying temperature was controlled by a temperature-control dial and air velocity of the drying chamber was measured by using thermal anemometer, model (Sato Sk-73D). A1000g from orange and mandarin peels was placed on the trays (100g each) and put in a drying chamber after the drying temperature reach to the setting point. Then, liable sample was taken to weight and moisture losses of samples were recorded hourly. The drying was continued until the samples reached $10 \%$, w.b., ideal for 
medicinal plants storage, since the recommended moisture content is 812\%, w.b., for medicinal plants, (Muller and Heindl, 2006). Another samples remained in the dryer until it reached the final moisture content. The experiments were replicated three times. The dried samples was cooled in a desicator and then packed in low density polyethylene bags that were heat-sealed until used. The data between moisture content and drying rate at various drying temperatures and drying time was plotted. The moisture ratio was evaluated as described by Wiriyaumpaiwong and Wiset, (2008).

$$
\mathrm{MR}=\left(\mathrm{M}-\mathrm{M}_{\mathrm{f}}\right) /\left(\mathrm{M}_{\mathrm{o}}-\mathrm{M}_{\mathrm{f}}\right)
$$

Where: $\mathrm{MR}=$ moisture ratio, dec.; $\quad \mathrm{M}=\mathrm{CP}$ moisture content at any time, w.b, \%;

$\mathrm{M}_{\mathrm{f}}=$ final moisture content, w.b., \%; and $\mathrm{M}_{\mathrm{o}}=$ initial moisture content, w.b., \%.

The final moisture content was determined according to Tanko et al., (2005) taking consideration that, the change in mass during drying the sample between two successive readings was eliminated.

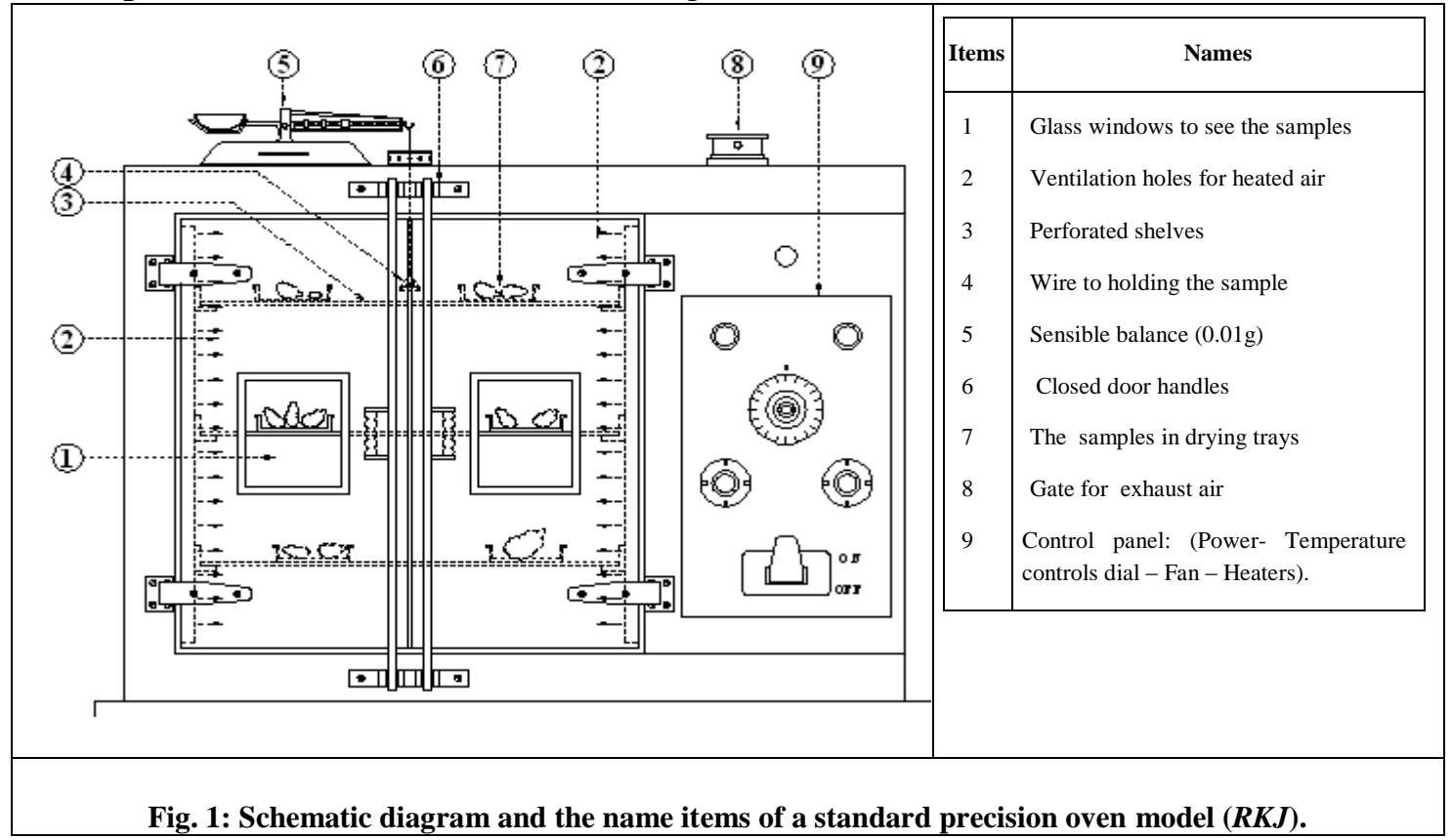

\section{Specific energy consumption:}

To evaluate specific energy consumption, the electric power consumption for each test was measured by using an electrical multi-meter, model 
(GG 150E) which connected at the source of power supply as reported by Shoughy et al., (2011) as follows:

$$
P, k W=N_{L} \cdot I_{L} \cdot \eta \cdot \cos \varphi / 1000 \text {. }
$$

Where: $\mathrm{N}_{\mathrm{L}}=$ electric potential, volt, being equal to 220 volt $\mathrm{I}_{\mathrm{L}}=$ electric current, ampere, $\quad \eta=$ fan efficiency (95\%), and $\operatorname{Cos} \varphi=$ power factor (0.85).

\section{Preparation of the samples:}

After drying at various drying temperatures, three replicated samples of $100 \mathrm{~g}$ for dried mandarin and orange peels were grounded by using a kitchen blender to obtain powder before analysis. The prepared CP powder was sealed in polyethylene bags to prevent moisture absorption and stored at $5 \pm 1^{\circ} \mathrm{C}$ for further studies.

\section{Gross chemical composition:}

Moisture content, crude protein ( $\mathrm{N}$ x 6.25), ash content, crude fibers content and ether extract of fresh and dried $\mathrm{CP}$ samples at various drying air temperatures were determined according to the methods of A.O.A.C., (2005).

\section{Vitamin $\mathrm{C}$, carotenoids and essential oils extraction and determination:}

Samples of fresh CP were taken for vitamin C, carotenoids and essential oil determination before the beginning of drying as a control sample to compare with the samples dried to 9.8 and $5.2 \%$ for orange peels and for mandarin peels, the moisture levels of 10.2 and $5.6 \%$,w.b., at $60-70^{\circ} \mathrm{C}$ drying air temperatures. The extraction of vitamin $\mathrm{C}$ (Ascorbic acid) from the CP was carried out as the method described by Javed et al., (2010). All materials needed were of analytical grade and purchased from chemical suppliers. Also, the essential oils of fresh and dried CP were extracted using water distillation method and calculated in $\mathrm{g}$ of oil $/ 100 \mathrm{~g}$ of samples according to the procedure described in A.O.A.C., (2005). Losses of essential oils were calculated based on the difference in essential oils content of fresh and dried samples. Carotenoids were extracted from fresh and dried CP by acetone according to the procedure of Megahed (1985). The following equation was used for calculation:

$$
\mathrm{X}=\left(\mathrm{E}_{\mathrm{y}} / \mathrm{E}_{1 \mathrm{Cm}}\right) \text {. }
$$

Where: $X=g$ of carotene, $y=m l$ of solution, $E=$ Absorbance at $450 \mathrm{~nm} \quad$ and $\mathrm{E}_{1 \mathrm{~cm}}=$ Specific extraction coefficient (2500). 


\section{Preparation of cakes from blendes with dried CP:}

The cakes were prepared by using the method of Hanneman, (1984). Preparation of cake was carried out using wheat flour samples replaced separately with $0,10,15$ and $20 \%$ of dried citrus by-products (orange and mandarin peels) powders. Wheat flour and other ingredients used in cake were obtained from local markets.

\section{Sensory analysis:}

Organoleptic evaluation of prepared cake was done by 10panelists from students and staff members in Food Technology Dept., Fac. of Agric., Kafrelsheikh Univ. using ten point hedonic-scale ratings for color, taste, aroma, texture, and overall acceptability according to the procedure described by Watts et al., (1989).

\section{Statistical Analysis:}

The simple exponential equation was used to describe the moisture ratios of citrus peels. The quality data of $\mathrm{CP}$ were analyzed by an analysis of variance $(\mathrm{p}<0.05)$ and the means separated by Duncan's multiple range tests (Duncan, 1995).

\section{RESULTS AND DISCUSSION}

\section{Moisture contents of CP:}

The results in Fig. 2. shows that, the drying temperature was effective in removing moisture from the fresh CP. Rapid moisture removed from peels was obvious in all experiments particularly at higher drying temperature, thus, the drying time needed to reach specified moisture content was decreased. While, the moisture removed from orange peels was faster than that of mandarin peels due to the mandarin peels have higher oil glands in the skin than orange peels, which reduce moisture movement during drying. Decreasing moisture content of mandarin peels from 79.6 to about $10.2 \%$, w.b. needed $12,10,8$ and $6 \mathrm{~h}$ at drying air temperature of $40,50,60$ and $70^{\circ} \mathrm{C}$ respectively. While for orange peels, decreasing moisture content from 76.4 to about $9.8 \%$, w.b. needed 10, 7 , 6 and $5 \mathrm{~h}$ at the same drying air temperature maintained above as shown in Fig.2. The higher temperature accelerated the moisture migration in biomaterial as its structure sensible to heat. This may be due to the fact that, higher temperature implies larger driving force for heat transfer (Nimmol et al., 2007). 


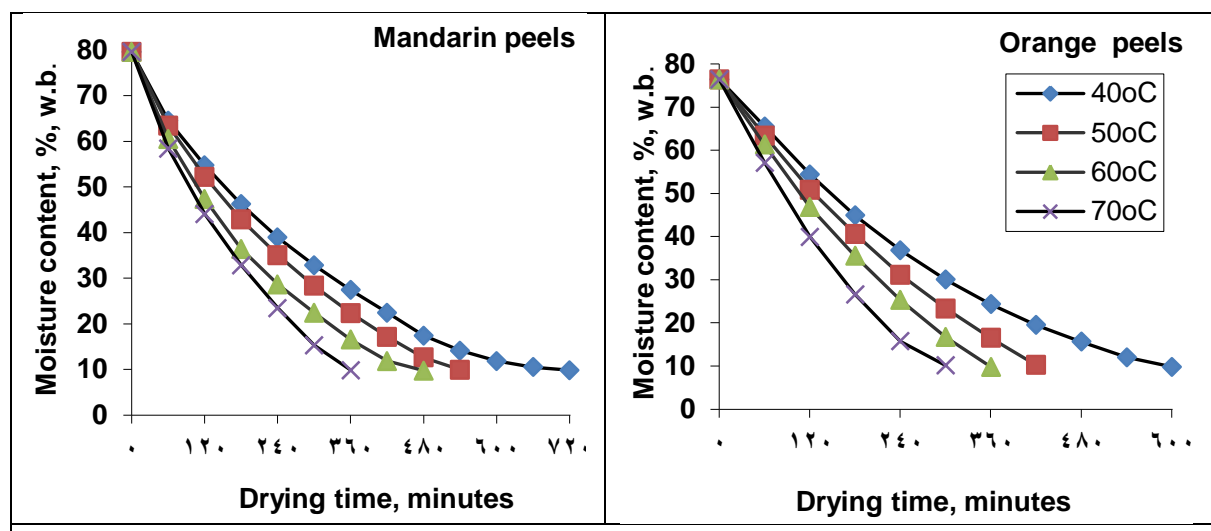

Fig. 2: Effect of drying temperatures on the moisture content of mandarin and orange peels.

\section{Drying rates of $\mathrm{CP}$ at various drying air temperatures:}

As expected, the drying rate of the Citrus peels was increased with increasing drying air temperatures as shown in Fig. 3. CP has a natural wax coat on their surfaces, which prevents most of the migration of moisture from the inside into the drying air. Faster evaporation rates were observed at higher temperatures due to the rapidly melting of the natural wax on the skin, thus, the drying time needed to reached specified moisture content was decreased. Also, the drying rate at the beginning of drying time was higher than that at the entre drying period. This was attributed to the fact that the product, which had high moisture content, dried faster than that of low moisture content at the same drying conditions. The average values of drying rates of mandarin peels were $5.5,7.6,9.6$ and $12.7 \% / \mathrm{h}$ with drying temperatures of 40, 50, 60 and $70^{\circ} \mathrm{C}$, respectively. While, the average values of drying rates of orange peels were $7.9,9.9,13.3$ and $15.9 \% / \mathrm{h}$ with the same drying air temperature maintained above. The reduction of drying time with increasing drying air temperature is desired in practice, because capacity of a dryer will be increased and allow for a considerable reduction of drying costs. While it has been documented that air temperatures above this range cause degradation of heat sensitive properties, air temperatures falling below this range will be unsuccessful in dehydrating herbs in time before spoilage occurs, Doymaz (2006). 


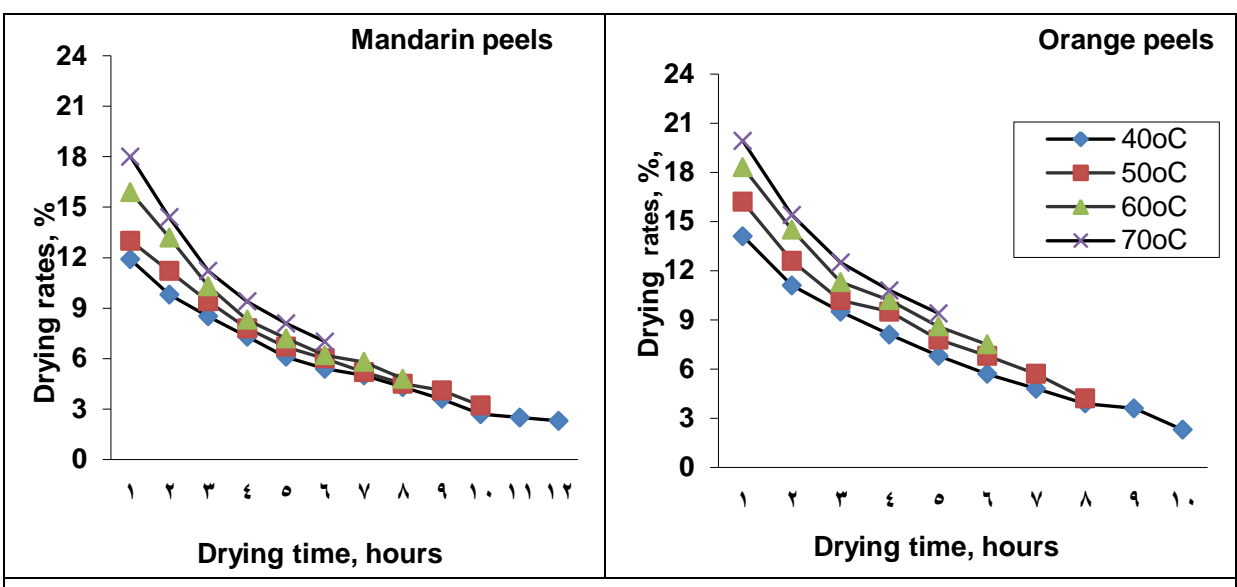

Fig. 3: Effect of drying temperatures on the drying rates of mandarin and orange peels.

\section{The Moisture ratio and required time to drying citrus peels:}

The experimental moisture ratio was obtained by using the exponential model for the hot air drying process by using Axial program as described by Doymaz (2006). The results showed that, the simple exponential equation satisfactorily described the drying behavior of CP as indicated by the higher coefficient of determination as shown in Fig. 4. The moisture ratios of citrus peels were decreased with increasing drying air temperatures and extended drying time and the values of moisture ratios of mandarin peels was higher than that of the orange peels. The time required for drying $\mathrm{CP}$ to the recommended moisture for storage and the final moisture content was considerably decreased with the increase in the drying air temperature as tabulated in Table 1. Also, Muller and Heindl, (2006) reported that, by increasing air temperature, drying time decreased exponentially. The final moisture content of mandarin peels was $6.5,5.1,4.2$ and $2.5 \%$, at drying air temperature of 40, 50, 60 and $70^{\circ} \mathrm{C}$, respectively, while, for orange peels, the final moisture content was $5.2,4.5,3.2$, and $1.8 \%$, at the same drying temperatures maintained above. The final moisture content decreases with increasing of the drying air temperature as well as the time needed to reach this final moisture level was decreased as reported by Kaya et al., (2007). This may be because when the temperature is increased, some water molecules are activated to energy levels that allow them to break away from their sorption sites, thus decreasing the final moisture content (Kouhila et al., 
2002). The knowledge about the required final moisture content will prevent over-drying and thus decrease drying time, energy costs, mass losses and the risk of quality deterioration; as drying to lower moisture content would cause additional operation costs and mass losses without increasing storage safety (Saeed et al., 2008).

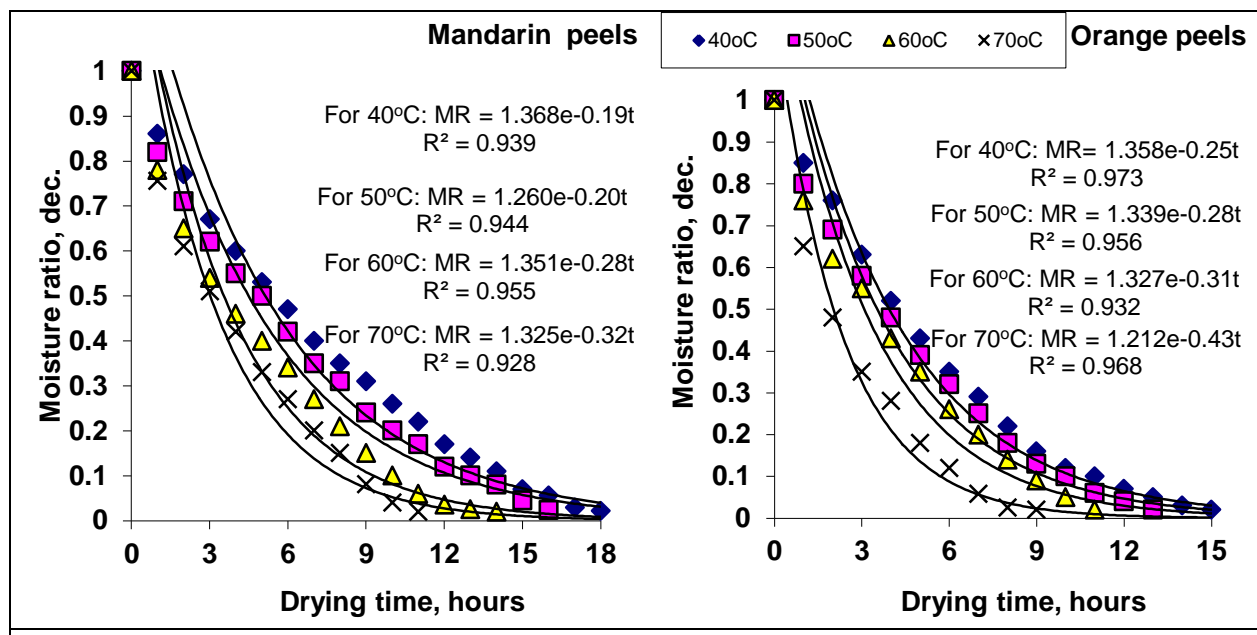

Fig.4: Effect of drying temperatures on the moisture ratio of mandarin and orange peels.

Table 1: The required time to drying citrus peels at various drying temperatures. Mandarin peels Orange peels

Drying time, $h$ Drying temperature, $\left({ }^{\circ} \mathrm{C}\right)$

\begin{tabular}{lcccccccc} 
& $\mathbf{4 0}$ & $\mathbf{5 0}$ & $\mathbf{6 0}$ & $\mathbf{7 0}$ & $\mathbf{4 0}$ & $\mathbf{5 0}$ & $\mathbf{6 0}$ & $\mathbf{7 0}$ \\
To moisture of 10 $\pm \mathbf{0 . 2 \%}$, w.b. & 12 & 10 & 8 & 6 & 10 & 7 & 6 & 5 \\
To final moisture level, \%, w.b. & 18 & 15 & 12 & 10 & 15 & 13 & 10 & 8 \\
\hline
\end{tabular}

\section{Specific energy consumption, $\mathrm{kJ} / \mathrm{kg}$ :}

Due to the high moisture content of the agriculture materials to be dried, energy demand of drying represents a significant cost factor, especially with the increased price of fossil fuels. Fig. 5 shows the specific energy consumption for drying $\mathrm{CP}$ with various drying air temperatures to save moisture level of storage $(10 \pm 0.2 \%$, w.b.). The results showed that the power consumption increased with increasing drying air temperature. While, the specific energy consumption was decreased from 5808 to $4170 \mathrm{~kJ} / \mathrm{kg}$ (by $28.2 \%$ decreasing rate) with increasing drying temperature from $40^{\circ} \mathrm{C}$ to $70^{\circ} \mathrm{C}$ for mandarin peels. Also, for orange peels, the 
specific energy consumption was decreased from 4840 to $3450 \mathrm{~kJ} / \mathrm{kg}$ (by $28.7 \%$ decreasing rate). This result may be due to the shorter drying time and higher drying rate was obtained with increasing drying temperature. This result was confirmed with the result obtained by Soysal and Oztekin (2001). Timesaving is an important management factor in drying and marketing of the dried products. It may be necessary to dry product as fast as possible to prevent product spoilage, minimize capital investment by rotating the drying equipment from one product to the other to meet market demand. The use of high temperature $\left(60\right.$ and $\left.70^{\circ} \mathrm{C}\right)$ to reduce drying time with quality preservation may be economical if the electrical power is at low prices and feasible.

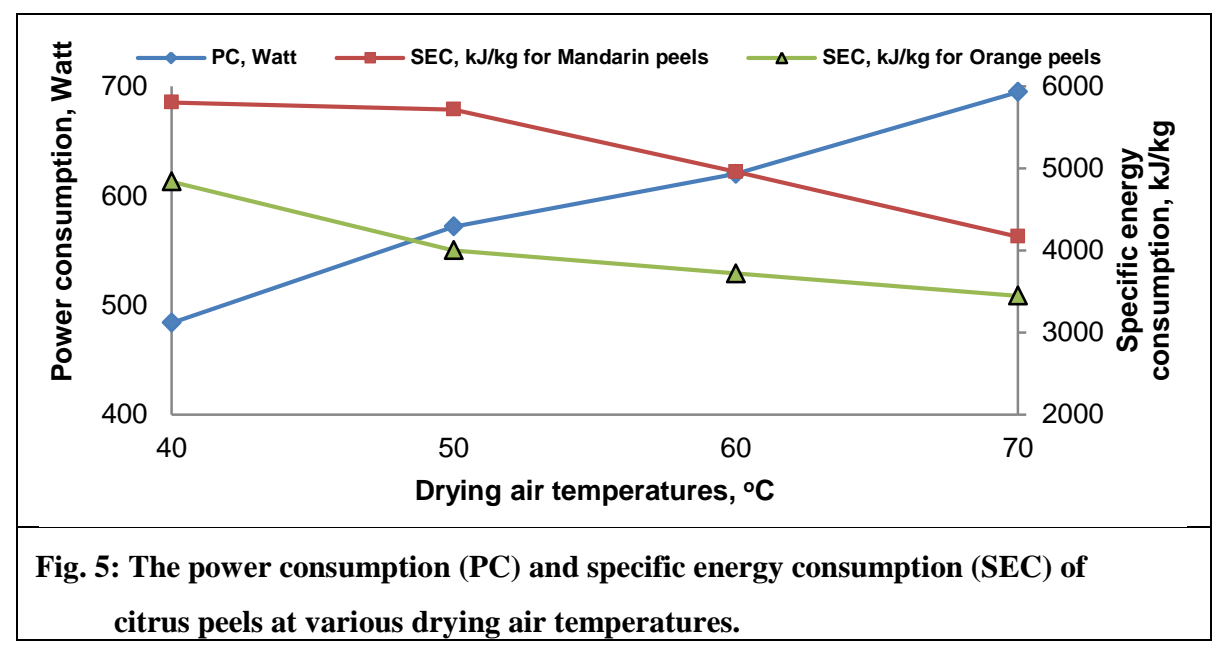

\section{Gross chemical composition of dried CP:}

Results from the primary experiments revealed that the chemical composition of $\mathrm{CP}$ after drying at 40,50 and $60^{\circ} \mathrm{C}$ to the residual moisture content of about $10 \pm 0.2 \%$ w.b., were not significantly different. However, the drying time for $\mathrm{CP}$ at 60 and $70^{\circ} \mathrm{C}$ was the shortest. Considering the time and energy consumption, the temperature of 60 and $70^{\circ} \mathrm{C}$ were, therefore, selected to use in the further experiment. Chemical composition of $\mathrm{CP}$ powder dried at 60 and $70^{\circ} \mathrm{C}$ to reach the desired moisture of 10.2 and $9.8 \%$ and final moisture content of 5.6 and $5.2 \%$ for mandarin and orange peels, respectively, as compared to fresh peels are presented in Table 2. Dried mandarin and orange peels had very low 
content of ether extract as compared with fresh peels. The decrease of ether extract increased with the increasing of drying temperature. This result related to the fact that $\mathrm{CP}$ contains high level of volatile compounds such as essential oils which was evaporated during the drying process. Also, there is no significantly deference in protein content of dried CP at high moisture content of 9.8-10.2\%, w.b., and fresh samples. While, the protein content and ether extract of samples dried to final moisture level of $5.4 \pm 0.2 \%$, w.b, for mandarin and orange peels was significantly decreased. The decrease in protein and ether extract contents of samples dried to low moisture level due to exposure the samples to heat for long time that leads to evaporate some volatile compounds such as nitrogen volatile compounds and essential oils. Also, Müller (2004) has clearly documented that the influence of high temperature on essential oils losses is high in the final phase, especially if material is over dried. The ether extract content of dried CP markedly decreased, protein and crude fiber contents slightly decreased, while, total carbohydrates increased with increasing drying air temperature from 60 to $70^{\circ} \mathrm{C}$.

Table 2: Chemical composition of fresh and dried CP powder (g/100g DW).

\begin{tabular}{|c|c|c|c|c|c|c|}
\hline Samples & Moisture, $\%$ & Protein & Ash & Ether extract & Crude fiber & $\begin{array}{c}\text { Total } \\
\text { Carbohydrates }\end{array}$ \\
\hline \multicolumn{7}{|l|}{ Orange peels } \\
\hline Fresh & 76.4 & $5.3 \pm 0.12 \mathrm{a}$ & $3.5 \pm 1.32 \mathrm{a}$ & $6.0 \pm 0.10 \mathrm{a}$ & $8.2 \pm 0.15 b$ & $85.2 \pm 1.3 \mathrm{c}$ \\
\hline Dried at $60^{\circ} \mathrm{C}$ & 9.8 & $5.2 \pm 0.02 \mathrm{a}$ & $3.5 \pm 0.15 \mathrm{a}$ & $3.6 \pm 0.12 b$ & $8.5 \pm 0.18 \mathrm{a}$ & $87.7 \pm 1.2 b$ \\
\hline $60^{\circ} \mathrm{C}$ & 5.2 & $5.0 \pm 0.15 b$ & $3.5 \pm 0.12 \mathrm{a}$ & $2.5 \pm 0.14 \mathrm{c}$ & $8.6 \pm 0.28 \mathrm{a}$ & $89.0 \pm 1.4 \mathrm{a}$ \\
\hline $7^{\circ} \mathrm{C}$ & 9.8 & $4.9 \pm 0.18 \mathrm{~b}$ & $3.5 \pm 0.15 \mathrm{a}$ & $3.1 \pm 0.22 b$ & $8.1 \pm 0.12 b$ & $88.5 \pm 1.5 \mathrm{a}$ \\
\hline $70^{\circ} \mathrm{C}$ & 5.2 & $4.7 \pm 0.13 c$ & $3.5 \pm 0.15 \mathrm{a}$ & $2.0 \pm 0.10 \mathrm{~d}$ & $7.8 \pm 0.12 \mathrm{c}$ & $89.8 \pm 1.5 \mathrm{a}$ \\
\hline \multicolumn{7}{|l|}{ Mandarin peels } \\
\hline Fresh & 79.6 & $6.2 \pm 0.15 \mathrm{a}$ & $3.5 \pm 0.20 \mathrm{a}$ & $8.5 \pm 0.23 \mathrm{a}$ & $7.9 \pm 0.35 \mathrm{a}$ & $81.8 \pm 1.1 \mathrm{c}$ \\
\hline Dried at $60^{\circ} \mathrm{C}$ & 10.2 & $6.0 \pm 0.13 b$ & $3.4 \pm 0.12 b$ & $5.8 \pm 0.02 b$ & $7.8 \pm 0.25 \mathrm{a}$ & $85.0 \pm 1.2 b$ \\
\hline $60^{\circ} \mathrm{C}$ & 5.4 & $5.8 \pm 0.18 \mathrm{c}$ & $3.5 \pm 0.02 \mathrm{a}$ & $3.0 \pm 0.02 \mathrm{c}$ & $7.9 \pm 0.20 \mathrm{a}$ & $87.7 \pm 1.6 \mathrm{a}$ \\
\hline $7^{\circ} \mathrm{C}$ & 10.2 & $5.9 \pm 0.12 c$ & $3.4 \pm 0.15 b$ & $5.1 \pm 0.22 b$ & $7.3 \pm 0.15 b$ & $85.6 \pm 1.3 b$ \\
\hline $7^{\circ} \mathrm{C}$ & 5.4 & $5.7 \pm 0.13 \mathrm{~d}$ & $3.5 \pm 0.10 \mathrm{a}$ & $2.2 \pm 0.18 \mathrm{~d}$ & $7.0 \pm 0.12 \mathrm{c}$ & $88.6 \pm 1.8 \mathrm{a}$ \\
\hline
\end{tabular}

The results are expressed as means $\pm \mathrm{SD}(\mathrm{n}=3)$. In each column different letters mean significant differences $(p<0.05)$. 


\section{Losses of vitamin C, carotenoids and essential oils:}

The results in Table 3 shows that, the fresh orange and mandarin peels contained high amounts of vitamin $\mathrm{C}$, carotenoids and essential oils. The loss of vitamin $\mathrm{C}$, carotenoids and essential oils of mandarin and orange peels were significantly increased with increasing drying air temperatures from 60 to $70^{\circ} \mathrm{C}$ and reduced dried moisture content from about 9.8$10.2 \%$ to $5.4-5.2 \%$, w.b, respectively. At the same drying temperature $\left(60^{\circ} \mathrm{C}\right)$, the loss of vitamin $\mathrm{C}$, carotenoids and essential oils was increased by $22.7,2.8$ and $33.4 \%$ for orange peels and by $22.9,3.1$ and $34.2 \%$ for mandarin peels dried to $10.2 \%$ moisture content. While, when drying to lower moisture level, the losses were increased by 44.9, 8.4 and $47.8 \%$ for orange peels and increased by 47.7, 9.0 and $50.1 \%$ for dried mandarin peels as compared to fresh peels. Also, increasing drying temperatures from 60 to $70^{\circ} \mathrm{C}$ tends to increasing the losses of vitamin $\mathrm{C}$, carotenoids and essential oils from 22.7 to $43.7 \%$, from 2.8 to $6.1 \%$ and from 33.4 to $41.0 \%$ for orange peels, while, for mandarin peels, the losses increased from 22.9 to $46.2 \%$, from 3.1 to $4.9 \%$ and from 34.2 to $52.7 \%$, when dried to $10 \pm 0.2 \%$, moisture level. Moreover, with increasing drying temperature from 60 to $70^{\circ} \mathrm{C}$, the losses of vitamin $\mathrm{C}$, carotenoids and essential oils increased by $80.5,13.5$ and $62.5 \%$ for orange peels dried to $5.2 \%$ moisture level, while, for mandarin peels dried to $5.6 \%$ moisture level, the losses of vitamin C, carotenoids and essential oils increased by $77.9,14.2$ and $64.3 \%$, respectively, as compared to fresh samples. The increase of nutritive value at lower temperature than that at higher temperature may be attributed to the increased availability of the compounds when exposed to moderate temperature $\left(60^{\circ} \mathrm{C}\right)$ at higher moisture content. This result was agreed with the results obtained by Garau et al., (2007). They found that hot air drying of orange peels around $50-60^{\circ} \mathrm{C}$ apparently promoted the minor disruption of cell wall polymers. Also, Jeong et al., (2004) found that appreciable decomposition of carotenoids was observed at high temperature between $70-90^{\circ} \mathrm{C}$ but at $105^{\circ} \mathrm{C}$ natural carotenoids were completely decomposed. Abdel-Hady (2013) found that the duration of exposure to heat had a great effect on carotenoids. Increased intake of vitamin $\mathrm{C}$, an important 
antioxidant found in fruits and vegetables, is strongly linked to reduced risk of many types of cancers, required in the conversion of fat into energy and in the proper functioning of the brain, Block (1991) and Javed et al., (2010).

Table 3: Losses of vitamin C, carotenoids and essential oil of dried CP.

\begin{tabular}{|c|c|c|c|c|}
\hline Samples & $\begin{array}{c}\text { Moisture, } \\
\%, \text { w.b. }\end{array}$ & Vitamin C (mg/100g) & $\begin{array}{c}\text { Carotenoids } \\
(\mathrm{mg} / 100 \mathrm{~g})\end{array}$ & Essential oils, \% \\
\hline \multicolumn{5}{|l|}{ Orange peels: } \\
\hline Fresh & 76.4 & $55.4 \pm 0.15 \mathrm{a}$ & $21.5 \pm 0.08 \mathrm{a}$ & $3.68 \pm 0.01 \mathrm{a}$ \\
\hline Dried at $60^{\circ} \mathrm{C}$ & 9.8 & $42.8 \pm 0.22 b$ & $20.9 \pm 0.02 \mathrm{a}$ & $2.45 \pm 0.02 \mathrm{~b}$ \\
\hline $60^{\circ} \mathrm{C}$ & 5.2 & $30.5 \pm 0.12 \mathrm{c}$ & $19.7 \pm 0.05 b$ & $1.92 \pm 0.03 \mathrm{c}$ \\
\hline $70^{\circ} \mathrm{C}$ & 9.8 & $31.2 \pm 0.02 \mathrm{c}$ & $20.2 \pm 0.03 \mathrm{a}$ & $2.17 \pm 0.02 \mathrm{~b}$ \\
\hline $70^{\circ} \mathrm{C}$ & 5.2 & $10.8 \pm 0.25 \mathrm{~d}$ & $18.6 \pm 0.16 \mathrm{c}$ & $1.38 \pm 0.02 \mathrm{~d}$ \\
\hline \multicolumn{5}{|l|}{ Mandarin peels: } \\
\hline Fresh & 79.6 & $62.5 \pm 0.10 \mathrm{a}$ & $32.4 \pm 0.03 \mathrm{a}$ & $4.71 \pm 0.02 \mathrm{a}$ \\
\hline Dried at $60^{\circ} \mathrm{C}$ & 10.2 & $48.2 \pm 0.03 \mathrm{~b}$ & $31.4 \pm 0.02 \mathrm{a}$ & $3.10 \pm 0.02 \mathrm{~b}$ \\
\hline $60^{\circ} \mathrm{C}$ & 5.6 & $32.7 \pm 0.02 \mathrm{c}$ & $29.5 \pm 0.10 \mathrm{~b}$ & $2.35 \pm 0.03 c$ \\
\hline $7^{\circ} \mathrm{C}$ & 10.2 & $33.6 \pm 0.10 \mathrm{c}$ & $30.8 \pm 0.15 \mathrm{ab}$ & $2.23 \pm 0.01 \mathrm{c}$ \\
\hline $70^{\circ} \mathrm{C}$ & 5.6 & $13.8 \pm 0.22 \mathrm{~d}$ & $27.8 \pm 0.25 \mathrm{c}$ & $1.68 \pm 0.02 \mathrm{~d}$ \\
\hline
\end{tabular}

The results are expressed as means $\pm \mathrm{SD}(\mathrm{n}=3)$. In each column different letters mean significant differences $(p<0.05)$. The values are expressed as a dry weight basis.

\section{Sensory evaluation of substituted cakes:}

Cakes prepared from blendes containing different proportions $(0,10,15$ and $20 \%$ ) orange and mandarin peels dried at $60^{\circ} \mathrm{C}$ to $10 \pm 0.2 \%$, w.b., moisture content as recommended samples, were evaluated for sensory characteristics and the results recorded in Table 4. The results show that dried orange and mandarin peels powder enhanced all sensory characteristics of cake comparing with the control. The enhancement increased with increasing the level of dried orange and mandarin peels powder up to $15 \%$. Mortensen, (2006) also reported that, carotenoids, specifically beta-carotene, are believed to enhance the function of the immune system and are the precursors of many important chemicals responsible for the flavor of foods. On the other hand, the sensory characteristics of the samples contained the highest level of orange and mandarin peels (20\%) has lower scores compared to control and the samples contained the lower levels of orange and mandarin peels. This may be attributed to the $\mathrm{CP}$ have high content of pigments which 
changed during baking resulted undesirable color especially at higher substitution level. In addition, CP contains high content of essential oils which contain some bitter compounds and give (at higher level) a bitter taste in the final product.

\section{Chemical composition of substituted cakes:}

Cakes prepared from blendes containing 0,10 , and 15\% orange and mandarin peels dried at $60^{\circ} \mathrm{C}$ to $10 \pm 0.2 \%$, w.b., moisture content as recommended samples, were evaluated for chemical composition.

Table 4: Sensory evaluation of cakes prepared using dried CP powder.

\begin{tabular}{cccccccc}
\hline Samples & Percent, $\%$ & Color & Taste & Aroma & Texture & $\begin{array}{c}\text { Overall } \\
\text { acceptability }\end{array}$ & $\begin{array}{c}\text { LSD } \\
(\mathbf{P ~ 0 . 0 5 )}\end{array}$ \\
Orange peels & $\mathbf{0}$ & 7.8 & 8.1 & 7.5 & 8.6 & 8.0 & 0.86 \\
& $\mathbf{1 0}$ & 8.2 & 8.3 & 8.6 & 8.6 & 8.2 & 0.75 \\
& $\mathbf{1 5}$ & 8.6 & 9.1 & 9.2 & 8.4 & 9.1 & 0.62 \\
Mandarin peels & $\mathbf{2 0}$ & 6.4 & 7.5 & 7.8 & 7.5 & 7.3 & 0.91 \\
& $\mathbf{0}$ & 7.8 & 8.1 & 7.5 & 8.8 & 8.1 & 0.86 \\
& $\mathbf{1 0}$ & 8.5 & 9.0 & 8.5 & 8.9 & 8.7 & 0.76 \\
& $\mathbf{1 5}$ & 9.4 & 9.4 & 9.2 & 8.7 & 9.2 & 0.65 \\
\hline
\end{tabular}

Table 5 shows the ash, ether extract and crude fiber contents increased with increasing the percent of citrus powders in cakes, while protein and total carbohydrates was decreased. Incorporation of $15 \%$ orange and mandarin peels in cakes formula significantly increased ash content by 30.6 and $29.0 \%$ and crude fiber content by 33.5 and $29.6 \%$, respectively, as compared to the control sample. This may be due to higher contents of ash and crude fiber constituents in CP. This result was in harmony with the results obtained by Bilgicli et al., (2007) and Nassar et al., (2008). Low carbohydrate diets have been reported to lower blood pressure by causing weight loss and improving the insulin sensitivity in diabetics (Arora and McFarlane, 2005). The total ash value is an indicator of the total minerals element in product. Also, fiber aids and speeds up the excretion of waste and toxins from the human body, preventing them from sitting in the intestine or bowel for too long, and thereby avoids a build-up of several diseases. 
PROCESS ENGINEERING

Table 5: Chemical composition of CP substituted cakes g/100g dry weight basis.

\begin{tabular}{cccccc}
\hline $\begin{array}{c}\text { Sample } \\
\text { Orange peels: }\end{array}$ & Protein & Ash & Ether extract & Crude fiber & Total Carbohydrates \\
\hline 0\% & & & & & \\
$\mathbf{1 0 \%}$ & $9.64 \pm 0.15 \mathrm{a}$ & $1.24 \pm 0.01 \mathrm{c}$ & $18.31 \pm 0.18 \mathrm{~b}$ & $3.82 \pm 0.20 \mathrm{c}$ & $70.81 \pm 2.12 \mathrm{a}$ \\
$\mathbf{1 5 \%}$ & $9.32 \pm 0.15 \mathrm{c}$ & $1.62 \pm 0.22 \mathrm{a}$ & $18.84 \pm 0.22 \mathrm{a}$ & $5.10 \pm 0.35 \mathrm{a}$ & $70.22 \pm 1.5 \mathrm{~b}$ \\
Mandarin peels: & & & & & \\
\hline $\mathbf{0 \%}$ & $9.64 \pm 0.15 \mathrm{a}$ & $1.24 \pm 0.02 \mathrm{c}$ & $18.31 \pm 0.18 \mathrm{~b}$ & $3.82 \pm 0.21 \mathrm{c}$ & $70.81 \pm 1.5 \mathrm{a}$ \\
$\mathbf{1 0 \%}$ & $9.48 \pm 0.22 \mathrm{~b}$ & $1.50 \pm 0.04 \mathrm{~b}$ & $18.83 \pm 0.20 \mathrm{a}$ & $4.53 \pm 0.35 \mathrm{~b}$ & $70.19 \pm 1.4 \mathrm{a}$ \\
$\mathbf{1 5 \%}$ & $9.40 \pm 0.01 \mathrm{~b}$ & $1.60 \pm 0.02 \mathrm{a}$ & $19.15 \pm 0.30 \mathrm{a}$ & $4.95 \pm 0.25 \mathrm{a}$ & $69.85 \pm 1.2 \mathrm{~b}$ \\
\hline
\end{tabular}

The results are expressed as means $\pm \mathrm{SD}(\mathrm{n}=3)$. In each column different letters mean significant differences $(p<0.05)$.

\section{CONCLUSIONS}

1. The drying air temperature was effective in removing moisture exponentially from citrus peels.

2. The mandarin peels had higher moisture ratios and slower drying rate for all drying temperatures than that of orange peels.

3. The drying time was decreased by $50 \%$ and specific energy consumption decreased by about $28.5 \%$ with increasing drying temperature from 40 to $70^{\circ} \mathrm{C}$ for drying citrus peels.

4. The optimal drying temperature was $60^{\circ} \mathrm{C}$ and $\mathrm{CP}$ dried to moisture content of about $10 \%$, w.b., to decrease drying time, save energy consumption and reduce the quality losses.

5. Overdrying to moisture levels of $5.4 \pm 0.2 \%$ with drying air temperature of $70^{\circ} \mathrm{C}$ for orange peels increased the losses of vitamin C, carotenoids and essential oils by 80.5, 13.5 and $62.5 \%$, while for mandarin peels, the losses increased by 77.9, 14.2 and $64.3 \%$.

6. Incorporation of orange and mandarin peels dried at $60^{\circ} \mathrm{C}$ to $10 \pm 0.2 \%$ moisture level in cakes formula significantly increased ash, ether extract and crude fiber contents, while protein and total carbohydrates contents slightly decreased.

7. Highly acceptable cakes could be obtained by incorporating $15 \%$ orange and mandarin peel powders in the formulation. 
It will further endorse $\mathrm{CP}$ as an important functional food which may prevent cancer in humans. This study will act as first line information to the researchers who are exploring the possibilities of converting waste to wealth, the concept which is currently evolving rapidly in the applied science branches from all possible dimensions.

\section{REFERENCES}

Abdel-Hady, Marwa, M. A. (2013). Utilization of food processing wastes in fortification of some foods and producing some biological compounds. M. Sc Thesis, Food sci. and Technol. Dept. Fac. of Agric. Kafrelsheikh Univ., Egypt.

A.O.A.C., (2005). Association of Official Analytical Chemists. Official Methods of Analysis of the Association of Official Analytical Chemists. Washington, USA.

Arora S. and S. McFarlane (2005). The case for low carbohydrate diets in diabetes management. Nutrition and Metabolism, 2:16.

Bilgicli, N., S. Ibanoglu and E.N. Herken (2007). Effect of dietary fiber addition on the selected nutritional properties of cookies. J. Food Eng., 78: 86-89.

Block, G. (1991). Vitamin C and Cancer Prevention: The Epidemiologic Evidence., Am. J. Clin. Nutr. 53:270-282.

Di Majo D., M. Giammanco, M. La Guardia, E. Tripoli, S. Giammancoand and E. Finotti (2005). Flavanones in Citrus fruit: Structure-antioxidant activity relationships. Food Res. Intern., 38: 1161-1166.

Djilas J.S. and C.B. Gordana (2009). By-products of fruits processing as a source of phytochemicals. Engineering Quarterly, 15(4):191-202.

Doymaz, I. (2006). Thin-layer drying behavior of mint leaves. Journal of Food Engineering, (74): 370-375.

Duncan, D. B. (1995). Multiple range tests and multiple $F$ test. Biometrics, 11: 1-42.

Garau, M.C., S. Simal, C. Rosselloó and A. Femenia (2007). Effect of air-drying temperature on physico-chemical properties of dietary 
fibre and antioxidant capacity of orange (Citrus aurantium v. Canoneta) byproducts. Food Chem., 104: 1014-1024.

Hanneman, L. J. (1984). Cake decoration in bakery powder confectionery, published by Heineman, London.

Inchuen S., W. Narkrugsal and P. ornchaloempong (2010). Effect of Drying Methods on Chemical Composition, Color and Antioxidant Properties of Thai Red Curry Powder. Kasetsart J. (Nat. Sci.) 44 : $142-151$.

Jayaprakasha G.K. and B.S. Patil (2007). In vitro evaluation of the antioxidant activities in fruit extracts from citron and blood orange. Food Chem., 101: 410-418.

Javed A., H. Abid and A. Hussain (2010). Study on some macronutrients composition in peels of different citrus fruits grown in NWFP (Pakistan).J. Chem. Soc. Pak., 32(1): 83-86.

Jeong, S. M., S.Y. Kim, D.R. Kim, S.C. Jo, K. C. Nam, D.U. Ahn and S.C. Lee (2004). Effect of heat treatment on the antioxidant activity of extracts from citrus peels. J. Agri. Food Chem., 52: 3389-3393.

Kaya, A., Aydin, O., Demirtas, C. and M. Akgün, (2007). An experimental study on the drying kinetics of quince. Desalination 212: 328-343.

Kong, K. W.; Khoo, H. E.; Prasad, K. N.; Ismail, A.; Tan, C. P. and Rajab, N. F. (2010). Revealing the Power of the Natural Red Pigment Lycopene. Molecules, 15(2): 959-987.

Kouhila, M., Kechaou, N., Otmani, M., Fliyou, M. and , S. Lahsasni (2002). Experimental study of sorption isotherms and drying kinetics of Moroccan Eucalyptus Globulus. Drying Technology 20(10): 2027-2039.

Lewicki, P. P. (2006). Design of hot air drying for better foods. Trends in Food Science and Technology, 17: 153-163.

Marin, F.R., C.R. Soler, G.O. Benavente, J. Castillo and A.J.A. Perez (2007). By-products from different citrus processes as a source of customized functional fibers. Food Chem., (100): 736-741. 
Megahed, M. Y. (1985). Studies on composition and antimicrobial effect of carrot carotenes. J. of Food Sci., 60(5):1048-1053.

Mortensen, A. (2006). Carotenoids and other pigments as natural colorants. Pure Appl. Chemistry, 78(8): 1477-1491.

Müller,J.,(2004). Drying of MAP. Teaching material. University Stuttgart-Hohenheim, Institute for Agricultural Engineering, Stuttgart.

Muller J. and A. Heindl (2006). Drying of medicinal plants. R.j. Bogers, 1.e. Craker and d. Lange (eds.), medicinal and aromatic plants: 237252.

Nassar, A.G., A.A. Abdel-Hamied and E.A. El-Naggar (2008). Effect of citrus by-products flour incorporation on chemical, rheological and organolepic characteristics of biscuits. World Journal of Agricultural Sciences, 4(5): 612-616.

Nimmol, C., S. Devahastin, T. Swasdisevi, and S. Soponronnarit (2007). Drying of banana slices using combined low-pressure superheated steam and far-infrared radiation. Journal of Food Engineering, 81: 624-633.

Sacilik, K., R. Keskin and A.K. Elicin, (2005). Mathematical modeling of solar tunnel drying of thin layer organic tomato. Journal of Food Engineering, 25(1):15-25.

Saeed, I.E. ; K. Sopian and Z. Z. Abidin (2008). Thin-Layer Drying of Roselle (I): Mathematical and Drying Experiments. Agricultural Engineering International: the CIGR Ejournal:1-25.

Sharma, G.P., R.C. Verma and S.V. Pathare (2005). Mathematical modeling of infrared radiation thin layer drying of onion slices. Journal of Food Engineering, 71(3): 282-286.

Shoughy, M. I., A. A. FL-Keway, and Y. T. Hendawy (2011). Rice bran pellets production by using expeller machine. Misr J. Ag. Eng., 28(4): 975-998.

Soysal Y. and S. Oztekin (2001). Technical and Economical performance of a tray dryer for medicinal and aromatic plants. J. Agric. Eng. Res., 79(1): 73-79. 
Watts, B. M., Ylimaki, G. L., Jeffery, L. E., and Elias, L. G. (1989). Basic Sensory Methods for Food Evaluation. IDRC, Ottawa, Ontario, Canada, pp 66-78.

Wiriyaumpaiwong, S. and L. Wiset (2008). Thin layer drying equation and the changes in color of celery under different drying temperatures. Agricultural Sci. J., 39(3): 323-326.

\section{الملخص العربي}

\section{تأثير درجات الحرارة علي سلوكيات التجفيف وجودة قشور الموالح

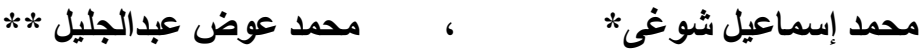

تنتج مصر سنويا كميات كبيرة من المو الح يتم استهلاك جزء كبير منها طازج ويتم تصدير

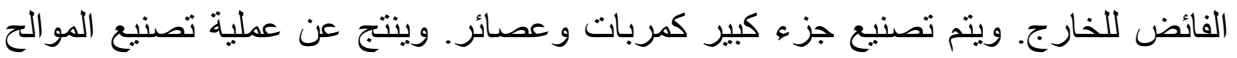

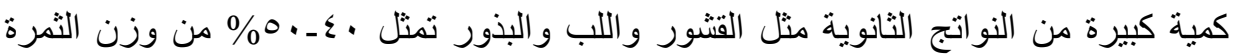

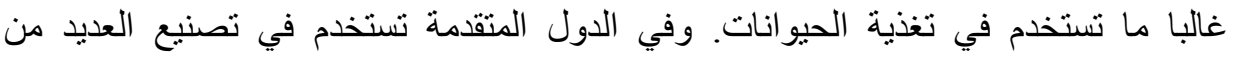
المنتجات مثل صناعة الادوية والعطور ومكسبات الطعم والقو ام ومكملات الاغذية. ولفية وهذه

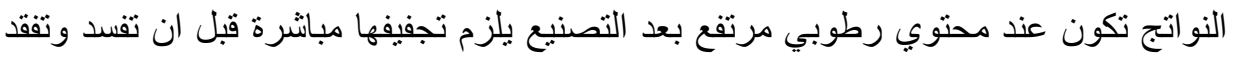

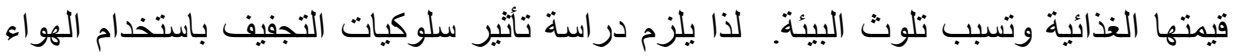

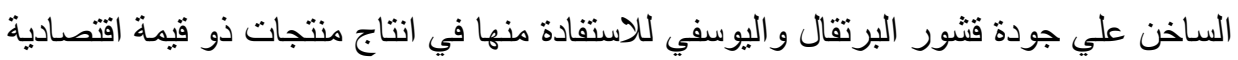
لزيادة الدخل القومي من الانتاج الزراعي.

دأهداف البحث: التجفيف ونسبة الرطوبة و الزمن اللازم لتجفيف فتور البرتقال واليوسفي وكذلك حساب الطاقة

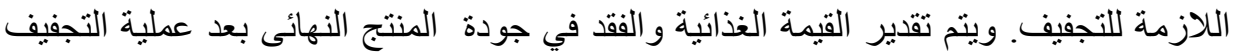
لمحتويات رطوبة مختلفة والتقدير الحسي للكيك المحتوي علي نسب مختلفة من قتور الموالح المجفةة.

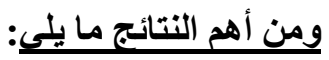

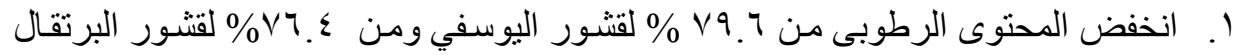

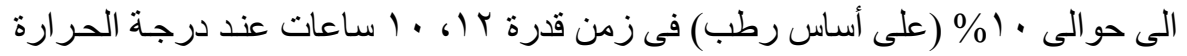

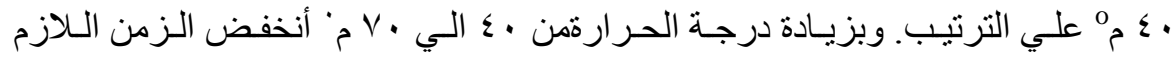
للتجفيف الي النصف و الطاقة النو عية اللازمة للتجفيف بمقدار 28.5\%.

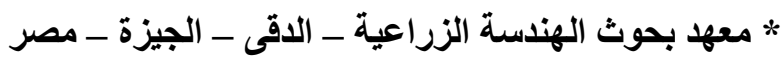

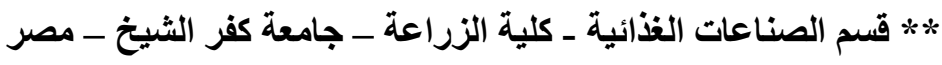




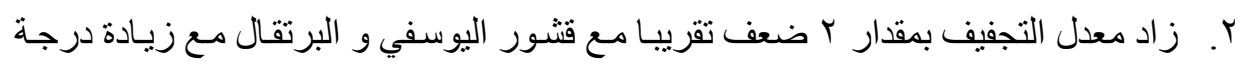

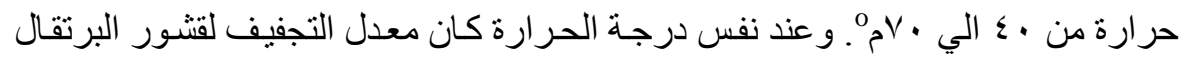
أعلي من قشور اليوسفي.

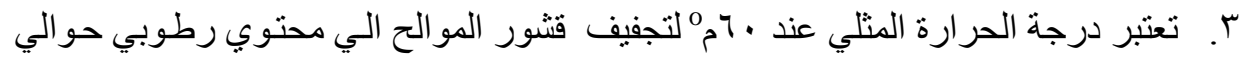

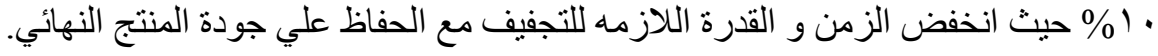
ع. ـ تحتوي قتنور المو الح المجفهه علي نسبة عالية من الكربو هيدر ات و الاليـاف الكلية وفيتـامين

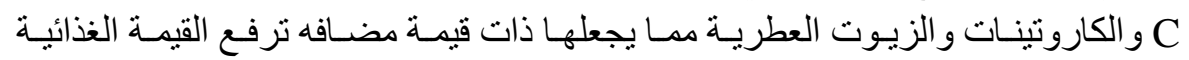
وتحسن الخواص الحسية للمنتجات.

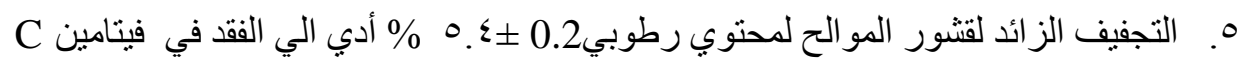

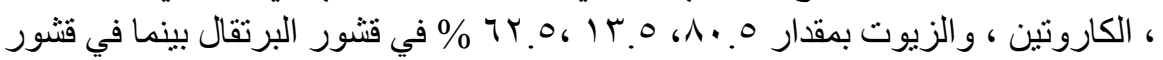

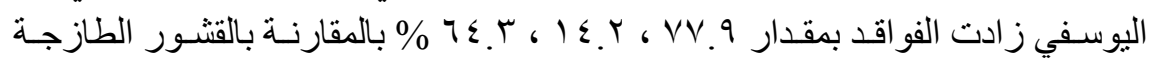
بالاضافه الي استهلاك الطاقة. 7. الاختبار الحسي للكيك المصنع من مسحوق المو الح المجفف حتي نسبة إستبدال بدقيق القمح

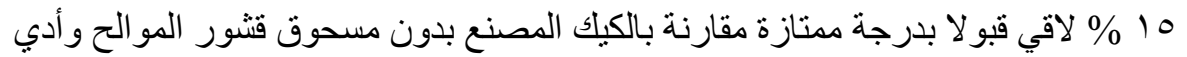

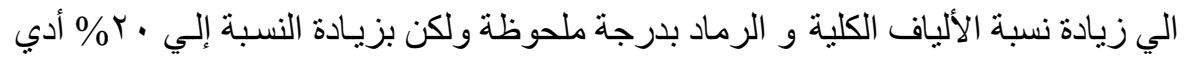

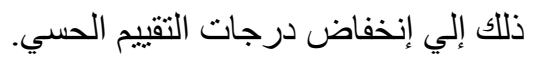

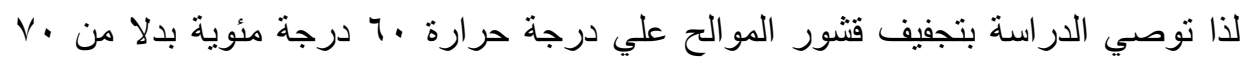

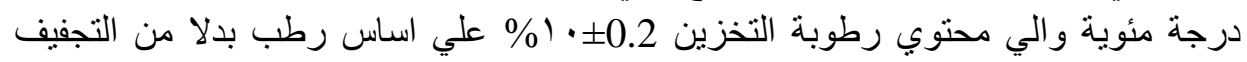

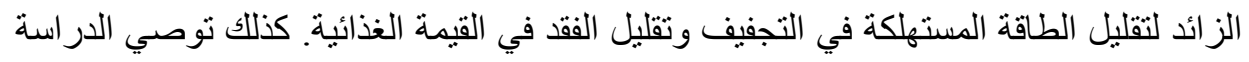
بالإستفادة من هذه القشور المجففة بإضافتها إلي بعض الأغذية مثل منتجات المخابز لتحسين خو اصها الحسية ورفع قيمتها الغذائية. 